FOOL'S CORNER

\title{
Stock-picking warm up
}

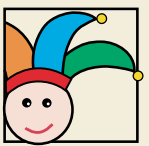

Tom Jacobs, of the Interne site Motley Fool (http://www. fool.com/), provides his angle on biotechnology investments. As Jacobs points out, "Industry insiders may know about biotechnology, but (as the song should go) 'it don't mean a thing, if you haven't learned sound investing principles." Read on and become "Foolishly" informed ${ }^{*}$. He can be contacted about biotechnology and investing at TomJ@ Fool.com. Jacobs cannot give individual investment advice but welcomes any.

Last month I detailed the steps that you should take before investing in stocks of individual companies. So, this month you are at the starting line, chomping at the bit, raring to go.

Whoa there, pardner! What's the hurry?

Actually, there is none. There will always be good investments-six minutes, six months, or even six years from now. But first, you are advised to run a few warm-up laps.

Put your feet up and crack open any of a number of excellent, educational-even fun-books on investment. Any book by Peter Lynch is a great start. And for how to examine businesses, it is hard to beat Lawrence Cunningham's The Essays of Warren Buffett. If you are concerned about the market's recent decline, our own fools, David and Tom Gardner, have just published What to Do With Your Money Now. Whatever you do, step gingerly past every book whose title contains "made easy," "make gazillions," "my secrets to..." or "Shaq or Beckham's path to riches."

Do not invest any money in stocks that you will need within five years. Whether you buy mutual funds or stocks, do not invest any money that you plan to spend during the next five years. This money is usually cash to buy a house, finance your own or your children's education, replace a car, or put a new thatched roof on the Lake Country cottage.

${ }^{*}$ Nature Biotechnology does not guarantee the veracity, reliability, or completeness of any information provided on this page; it is not responsible for any errors or omissions or for any results obtained from the use of such information; it will not be liable for any loss, damage, or investment decision arising from a reader's reliance on the information provided.
Put that money in an interest-bearing account and sleep well.

Research shows that stock prices in the short term behave as predictably as six-yearolds on sugar. But in the longer term-five years or longer-stock prices tend to follow (up or down) a business's ability to create value. You will make good and bad choices, but the longer you hold onto your stocks, the better the chance that you will be rewarded for the good ones.

Start with what you know and learn more. Choose companies whose businesses you understand, either through your own work or your passion to learn, and read everything you can about the companies and their management. Do not buy companies based on tips or rumors, or even mentions in this column, without applying the same criteria that you would to evaluate any other company before being satisfied that it would make a good investment.

Invest your money periodically, not in a lump sum. This is called dollar-cost averaging, and it smoothes out your purchase price by spreading out your investments over the inevitable swings in the market. Begin investing gradually, starting with one or two stocks, and add more as you gain confidence.

Consider direct stock purchase plans. You need a lot of money to buy stocks, right? Wrong. Many well-known companies, such as Johnson \& Johnson, Intel, and Coca-Cola, allow you to purchase stock directly, bypassing the broker. This means you can often purchase fractional shares with as little as $\$ 20$ at a time. You can invest on a regular basis, say monthly or quarterly, and over time build up a nest egg. You must be a good record keeper: hold onto all your statements so that when you cash in your investment at retirement your accountant does not strangle you and shorten your golden years.

Put most of your money in companies that dominate their industries, have recognizable consumer brands, manageable debt, and long histories of profitability. Although some of the industry leaders are easy to evaluate (Microsoft versus Apple, Intel versus Advanced Micro Devices, Johnson \& Johnson versus Bristol-Myers Squibb) others require reading a company's annual reportand not just browsing through the pretty pictures designed by the company's spin doctors (and you thought only politicians had them!). I have previously stressed the importance of careful reading of company financial reports (Nat. Biotechnol. 20, 219, 2002). You should not invest in any company whose cash and short-term investments are $<1.5$ times its debt. If you do buy such a company's shares, do not pay too high a price for them. Learn how to calculate and use valuation ratios to make sure that your company's stock is reasonably priced. If the business performs well, its stock will reward you.

Go with the flow. Do not expect an uninterrupted string of earnings growth. Even the best-managed business occasionally hits a bad quarter or year. In fact, be cautious about uninterrupted profit growth, which may indicate that the management is manipulating earnings through accounting gimmicks rather than giving you the real-life picture of the company's financial ups and downs. You want the trend to be good, not perfect.

The drug industry provides examples of the bumps you can expect as an investor: Bristol-Myers Squibb (New York) makes a horrendous \$2 billion deal with ImClone Systems (New York) for rights to its cancer drug candidate Erbitux. A jury hits Genentech (S. San Francisco, CA) with a $\$ 500$ million compensation payout to the City of Hope National Medical Center (Duarte, CA and see Nat. Biotechnol. 20, 763, 2002). The Food and Drug Administration (Rockville, MD) delays action on Eli Lilly (Indianapolis, IN) and ICOS Pharmaceutical's (Bothell, WA) erectile dysfunction drug Cialis. The big drug makers mentioned here are more than likely to survive and prosper, but their business challenges have provided a few stomach-churning dives for their shareholders over the short term.

Invest in risky, unproven companies-if at all-with only a small part of your portfolio. Risky companies should occupy less than $20 \%$ of your total investment, and should enter your portfolio only after you have substantial experience investing. Most readers will choose biotechnology companies for investments in this category, simply out of familiarity. If you choose riskier, unprofitable, emerging biotechnology companies, stick with those whose science you understand and that have the cash to survive until their drugs come to market (see Nat. Biotechnol. 20, 543, 2002). If you want to consider investments outside of the pharmaceutical sector, be sure you understand their market, products, competition, and whether they have a niche or larger market.

Finally, consider forming an investment club with friends and learning together. In fact, that is what the Sitting Pretty Investment Club does in this space regularly.

Have a great month! 